\title{
JUKMAS
}

Jurnal Untuk Masyarakat Sehat (JUKMAS)

e-ISSN : 2715-7687

Vol. 4, No. 1 April 2020

P-ISSN : 2715-8748

\section{Analisa Postur Pengendara Motor Untuk Evaluasi Dimensi Bagian Tempat Duduk Menggunakan Metode Reba}

\author{
Anggita Rahmawati, Dessy Laksyana Utami \\ Program Studi Kesehatan Masyarakat, Fakultas IImu Kesehatan, Universitas Respati \\ Indonesia \\ Email : dessy_lakutami908@gmail.com
}

\begin{abstract}
ABSTRAK
Saat ini sepeda motor menjadi pilihan sebagai alat transportasi yang diminati, meskipun kecelakaan kendaraan bermotor meningkat setiap tahunnya. Rancangan sepeda motor harusnya dapat menjadi prioritas untuk lebih ergonomis agar dapat mengurangi kelelahan pengendara seminimal mungkin. Analisa postur tubuh saat berkendaraan menjadi perhatian serius, bila dimensi sepeda motor dan antropometri pengendara tidak sesuai, artinya sepeda motor tidak ergonomis, maka terjadi kelelahan yang mengakibatkan kecelakaan. Target penelitian ini untuk mengevaluasi dimensi sepeda motor di bagian sekitar tempat dudukan dan merekomendasikan rancangan dimensi baru khusus sepeda motor tipe bebek metik. Penggunaan pendekatan metode Rapid Entire Body Assessment (REBA) pada pengendara motor dapat mengevaluasi postur pengendara dengan skor REBA worksheet untuk mendapatkan gambaran kondiri postur yang ergonomik. Dengan survei yang dilakukan mendapatkan data dari pengendara untuk membuktikan postur yang tidak ergonomik. Kondisi postur yang tidak ergonomik mungkin disebabkan adanya dimensi sadel sepeda motor yang tidak memenuhi dasar antropomentri. Adapun skor REBA worksheet untuk mendapatkan gambaran kondisi postur untuk jarak $34 \mathrm{~cm}$ dari ujung sadel skornya 5 , kondisi postur untuk jarak $44 \mathrm{~cm}$ dari ujung sadel skornya 8. Resiko untuk skor 8 pada kategori level tinggi, kondisi berbahaya dan diperlukan tindakan pemeriksaan dan perubahan postur segera.
\end{abstract}

Kata kunci: Ergonomi, Antropometri, REBA worksheet

\section{ABSTRACT}

Currently the motorcycle of choice as a means of transportation that is in demand, despite increased motor vehicle accidents every year. The design of his motorcycle should be a priority for a more ergonomic in order to reduce rider fatigue to a minimum. Analysis posture of the body while driving is a serious concern, if the dimensions of the motorcycle and the rider is not appropriate anthropometric means motorcycles are not ergonomic, there will be fatigue which lead to an accident. The target of this study is to evaluate the dimensions of the motorcycle section around a place holder and recommend draft a new dimension of motorcycles automatic type. Use of approach methods Rapid Entire Body Assessment (REBA) on the motorist can evaluate 
the posture of the rider with a score of REBA worksheet to get an overview kondiri ergonomic posture. Based on a survey conducted to obtain data from the riders to prove that is not ergonomic posture. Conditions ergonomic posture may be due to demention saddle motorcycles that do not meet basic anthropomentry. The score of REBA worksheet to get an idea of the condition of the posture for a distance of $34 \mathrm{~cm}$ from the tip of the saddle score is 5 , the posture condition for a distance of $44 \mathrm{~cm}$ from the tip of the saddle the score 8, . Risk score to a score of 8 in the category of high-level, dangerous conditions and necessary due diligence measures and changes in posture immediately.

Keywords : Ergonomi, Antropometri, REBA worksheet

\section{PENDAHULUAN}

Dalam biomekanika kerja tubuh dipandang sebagai suatu sistem mekanik. Sistem ini terkait dengan sistem kerangka otot. Sistem kerangka otot meliputi tulang, otot, ligamen, tendon, lapisan fascia dan tulang rawan (Valero et. al., 2016) (Wickens and Hollands, 2004) (Bender et al., 2005) (Torik et. al., 2013). Biomekanika Kerja terkait juga dengan jenis pekerjaan yang bersifat fisik seperti pekerjaan-pekerjaan penanganan.

Saat ini kendaraan sepeda motor menjadi pilihan sebagai alat transportasi yang diminati, meskipun kecelakaan kendaraan bermotor meningkat setiap tahunnya. Pengendara sepeda motor bila mengendara dengan jarak tempuh yang jauh harus bisa memposisikan duduk yang layak.

Selain faktor di luar orang (pengendara) memang ada faktor yang menyebabkan terjadi kecelakaan, misalnya jalan yang rusak, penerangan yang gelap, sepeda motor yang tidak baik atau tidak dirawat. Tetapi penyebab utama lebih ditekankan pada faktor manusianya. Cara pengendara motor yang umum (bukan pembalap) lebih mempertimbangakan kondisi badan yang sehat, tetapi cara duduk kurang menjadi perhatian. Cara duduk di sepeda motor hanya selera seenaknya menurut gaya dilihat orang lain. Cara duduk di sepeda motor merupakan bagian dari postur tubuh yang harus diperhatikan, jika tidak layak akan memberikan pada bagian postur tubuh lain akan berpengaruh, sehingga timbul keseimbangan tubuh yang tidak layak dan akan memberikan keterbatasan gerak dan kelelahan.

Pada penelitian ini posisi postur pengendara yang dapat dijadikan sebagai input untuk memperbaiki posisi duduk pengendara, sehingga dapat memberikan lebih ergonomis kondisi tersebut dianalisa lebih mendetail. Penelitian ini bertujuan untuk menganalisa postur posisi pengendara sepeda motor untuk mendapatkan postur kerja yang lebih 
alamiah dalam mengatasi keluhan musculoskeletal system disorder (MSDs). Manfaat yang diharapkan dari penelitian ini untuk dapat digunakan sebagai bahan masukan dalam melakukan perbaikan sistem kerja yang berkaitan dengan postur kerja yang ergonomis kepada pengendara sepeda motor serta untuk mendapatkan postur kerja yang lebih alamiah dalam mengatasi keluhan musculoskeletal system disorder (MSDs).

\section{KAJIAN PUSTAKA}

\section{Biomekanika Kerja}

Disiplin Human Factor (faktor manusia) dalam ergonomi mempunyai definisi sebagai berikut (Sanders, 2003): "Human Factor adalah pengetahuan tentang manusia, keterbatasan, kelebihan dan karakterisitik manusia lainnya yang relevan dalam suatu perancangan". Dengan mengaplikasikan aspek-aspek ergonomi atau Human Engineering, maka dengan memanfaatkan informasi mengenai sifat, kemampuan, keterbatasan manusia dan lingkungan kerja dapat dirancang sebuah stasiun kerja yang bisa dioperasikan oleh ratarata manusia sehingga orang dapat hidup dan bekerja pada sistem tersebut dengan baik. Dalam arti dapat mencapai tujuan yang diinginkan melalui aktivitas tersebut dengan efektif, efisien, aman dan nyaman.
Maksud dan tujuan dari disiplin ergonomi adalah mendapatkan suatu pengetahuan yang utuh tentang permasalahan-permasalahan interaksi manusia dengan teknologi dan produknya, sehingga dimungkinkan adanya suatu rancangan fisik yang dimiliki oleh setiap pekerja berbeda-beda dan salah satu faktor yang mempengaruhi perbedaan kekuatan fisik itu adalah kekuatan otot. Namun, hal ini tidak terlalu diperhatikan dengan baik oleh perusahaan, sehingga seringkali pekerja mengalami cidera- cidera otot pada bagian punggung, leher, tangan, dan bagian tubuh lainnya. Cidera tersebut merugikan perusahaan karena kemampuan kerja seseorang tidak akan maksimal, jika mengalami keluhan otot.

Masalah nyeri punggung bawah yang timbul akibat duduk lama menjadi fenomena yang sering terjadi saat ini. Sebanyak $60 \%$ orang dewasa mengalami nyeri punggung bawah karena masalah duduk yang terjadi pada mereka yang bekerja atau yang aktivitasnya lebih banyak dilakukan dengan duduk. Duduk lama dengan posisi yang salah dapat menyebabkan otot-otot punggung menjadi tegang dan dapat merusak jaringan lunak sekitarnya. Bila keadaan ini berlanjut, dapat menyebabkan penekanan pada bantalan saraf tulang belakang yang mengakibatkan hernia 
nukleus pulposus (Cheng and Lee, 2006) (Henny et al., 2012) (Laviere at al., 2009). Keluhan nyeri punggung bawah akan mulai dirasakan setelah 6 bulan, apabila pengendara sepeda motor secara rutin berkendara setiap hari minimal 2,5 jam (Sukarto, 2006).

Diperkirakan kejadian low back pain pada pengendara sepeda motor dapat mengganggu aktivitas sehari-hari, menurunkan produktivitas dan efisiensi kerja, meningkatkan resiko kecelakaan kerja serta penyakit jangka panjang jika dibiarkan. Maka dari itu, perlu adanya penelitian untuk memecahkan solusi bagi pengendara sepeda motor dengan harapan timbulnya keluhan nyeri punggung bawah dapat diminimalisir atau dicegah sehingga gangguan- gangguan yang disebabkan oleh nyeri punggung bawah, seperti penurunan tingkat produktivitas dapat dicegah. Berdasarkan penjelasan tersebut, penelitian ini bertujuan mengidentifikasi dan mengevaluasi pengaruh sarana kerja (sepeda motor), postur kerja dan posisi kerja pengendara sepeda motor dengan menggunakan metode Rapid Entire Body Assessment (REBA).

\section{Rapid Entery Body Assessment (REBA)} REBA atau Rapid Entery Body Assessment dikembangkan oleh Dr. Sue Hignett dan Dr. Lynn Mc Atamney (2000) yang merupakan ergonom dari Universitas di Nottingham (University of Nottingham's Institute of Occuptaional Ergonomic). Rapid Entire Body Assissment (REBA) adalah suatu metode dalam bidang ergonomi yang digunakan secara cepat untuk menilai postur leher, punggung, lengan, pergelangan tangan dan kaki seorang pekerja. Metode ini juga dilengkapi dengan faktor coupling, beban eksternal, dan aktivitas kerja (Sukania et. al. 2016). Penilaian dengan menggunakan REBA tidak membutuhkan waktu yang lama untuk melengkapi dan melakukan scoring general pada daftar aktivitas yang mengindikasikan perlu adanya pengurangan resiko yang diakibatkan postur kerja operator (Hignett and McAtamney, 2000). Dalam metode ini, segmen-segmen tubuh dibagi menjadi dua grup, yaitu grup A dan Grup B. Grup A terdiri dari punggung (batang tubuh), leher dan kaki. Sedangkan grup B terdiri dari lengan atas, lengan bawah dan pergelangan tangan. Penentuan skor REBA, yang mengindikasikan level risiko dari postur kerja, dimulai dengan menentukan skor A untuk postur- postur grup A ditambah dengan skor beban (load) dan skor B untuk postur-postur grup B ditambah dengan skor coupling. Kedua skor tersebut (skor A dan B) digunakan untuk menentukan skor C. Skor 
REBA diperoleh dengan menambahkan skor aktivitas pada skor

Dari nilai REBA dapat diketahui level risiko cedera.

Pengembangan Rapid Entire Body Assissment (REBA) terdiri atas 3 (tiga) tahapan, yaitu:

1. Mengidentifikasikan kerja

2. Sistem pemberian skor

3. Skala level tindakan yang menyediakan sebuah pedoman pada tingkat yang ada, dibutuhkan untuk mendorong penilaian yang lebih detail berkaitan dengan analisis yang didapat.

REBA dikembangkan tanpa membutuhkan piranti khusus. Ini memudahkan peneliti untuk dapat dilatih dalam melakukan pemeriksaan dan pengukuran tanpa biaya peralatan tambahan. Pemeriksaan REBA dapat dilakukan di tempat yang terbatas tanpa menggangu pekerja. Pengembangan REBA terjadi dalam empat tahap. Tahap pertama adalah pengambilan data postur pekerja dengan menggunakan bantuan video atau foto, tahap kedua adalah penentuan sudut-sudut dari bagian tubuh pekerja, tahap ketiga adalah penentuan berat benda yang diangkat, penentuan coupling, dan penentuan aktivitas pekerja. Dan yang terakhir, tahap keempat adalah perhitungan nilai REBA untuk postur yang bersangkutan. Dengan didapatnya nilai REBA tersebut dapat diketahui level risiko dan kebutuhan akan tindakan yang perlu dilakukan untuk perbaikan kerja.

Penilaian postur dan pergerakan kerja menggunakan metode REBA melalui tahapan- tahapan sebagai berikut (Hignett and Mc Atamney, 2000) (Guild et. al., 2010):

1. Pengambilan data postur pekerja dengan menggunakan bantuan video atau foto Untuk mendapatkan gambaran sikap (postur) pekerja dari leher, punggung, lengan, pergelangan tangan hingga kaki secara terperinci dilakukan dengan merekam atau memotret postur tubuh pekerja. Hal ini dilakukan supaya peneliti mendapatkan data postur tubuh secara detail (valid), sehingga dari hasil rekaman dan hasil foto bisa didapatkan data akurat untuk tahap perhitungan serta analisis selanjutnya.

2. Penentuan sudut-sudut dari bagian tubuh pekerja. Setelah didapatkan hasil rekaman dan foto postur tubuh dari pekerja dilakukan perhitungan besar sudut dari masing-masing segmen tubuh yang meliputi punggung (batang tubuh), leher, lengan atas, lengan bawah, pergelangan tangan dan kaki. Pada metode REBA segmen-segmen tubuh tersebut dibagi menjadi dua kelompok, yaitu grup A dan B. Grup 
A meliputi punggung (batang tubuh), leher dan kaki. Sementara grup B meliputi lengan atas, lengan bawah dan pergelangan tangan. Dari data sudut segmen tubuh pada masing-masing grup dapat diketahui skornya, kemudian dengan skor tersebut digunakan untuk melihat tabel $A$ untuk grup $A$ dan tabel B untuk grup B agar diperoleh skor untuk masingmasing Tabel 1.

Tabel 1. Skor Reba

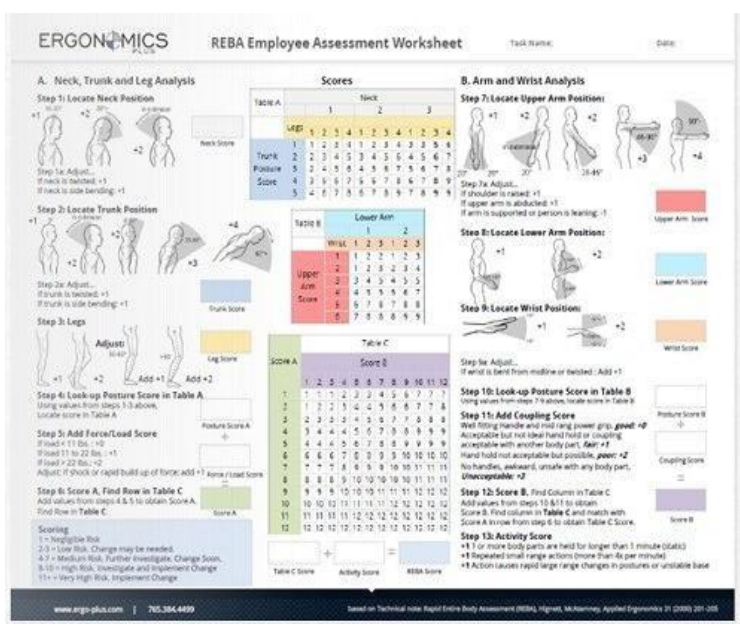

(SUMBER: MC. ATAMNEY AND CORLETT, 1993)

TABEL 2. Level Risiko

\begin{tabular}{|c|c|c|c|}
\hline Action Level & Skor REBA & Level Resiko & Tindakan Perbaikan \\
\hline 0 & 1 & Bisa Diabaikan & Tidak perlu \\
\hline 1 & $2-3$ & Rendah & Mungkin perlu \\
\hline 2 & $4-7$ & Sedang & Perlu \\
\hline 3 & $8-10$ & Tinggi & Perlu segera \\
\hline 4 & $11+$ & Sangat Tinggi & Perlu saat ini juga \\
\hline \multicolumn{4}{|c}{ (Sumber : A Step-by-Step Guide to the REBA Assessment Tool, 2013) }
\end{tabular}

\section{METODE}

\section{Instrumen Penelitian}

Instrument penelitian adalah alatalat yang digunakan untuk pengumpulan data. Instrumen penelitian sangat mendukung dalam analisa dan pengambilan data di lokasi penelitian. Adapun peralatan yang digunakan dalam penelitian ini antara lain adalah: kamera, yang berfungsi untuk memfoto postur kerja dan REBA worksheet, yang digunakan untuk menilai setiap pergerakan lengan atas (upper arm), lengan bawah (lower arm), pergelangan tangan (wrist), leher (neck), punggung (trunk), kaki (legs) serta mengukur beban (load/force) dan kegiatan (activity).

Tahap-tahap kegiatan penelitian

Studi Literatur / Pustaka

Pada bagian ini merupakan landasan teori yang digunakan antara lain, Aturan kerja (Ergonomi), Lingkungan Kerja, REBA worksheet. Studi literatur dilakukan untuk memberikan kerangka berpikir yang sistematis kepada penulis tentang pemecahan masalah untuk menganalisa lebih mendalam.

\section{Studi Lapangan}

Melakukan observasi sample dan pembuatan instrument penelitian, serta mengindentifikasi permasalahan untuk membuat latar belakang masalah, rumusan masalah, batasan masalah dan membuat tujuan penelitian.

Pengumpulan Data 
Pada tahap ini mulai dilakukan langkah- langkah pengumpulan data yang dibutuhkan untuk mencapai tujuan penelitian. Penelitian dilakukan dengan waktu efektif yang digunakan selama beberapa hari. Penelitian dilakukan pada setiap sikap postur tubuh statik yang terkait dengan pengendara sepeda motor.

\section{Pengolahan Data}

Pengolahan data dilakukan dalam beberapa tahap. Pertama, data pengamatan didapat dengan menggunakan data REBA worksheet untuk mengukur postur kerja dengan cara membagi pengamatan tubuh pengawai administrasi ke dalam 2 (dua) grup, yaitu grup A dan B. Kedua adalah menentukan skor REBA dari hasil kombinasi perhitungan skor $A$ dan skor $B$. Kemudian, ketiga adalah menentukan level tindakan dari perhitungan REBA pada postur kerja.

\section{HASIL DAN PEMBAHASAN}

\section{Data postur kerja}

Pengendara sepeda motor dengan sikap kerja duduk. Jarak duduk pengendara dari ujung sadel adalah $34 \mathrm{~cm}$ , maka lengan atas membentuk sudut 20$45^{\circ}$, lengan bawah membentuk sudut 0 $60^{\circ}$, pergelangan tangan membentuk sudut $>15^{\circ}$, kaki membentuk sudut $60^{\circ}$ dan batang tubuh membentuk sudut 0 $20^{\circ}$.

Jarak duduk pengendara dari ujung sadel adalah $44 \mathrm{~cm}$, maka lengan atas membentuk sudut $45-90^{\circ}$, lengan bawah membentuk sudut $0-60^{\circ}$, pergelangan tangan membentuk sudut $>15^{\circ}$, kaki membentuk sudut $60^{\circ}$ dan batang tubuh membentuk sudut $20-60^{\circ}$. Hal ini diperlihatkan pada Gambar 1 dan Gambar 2.

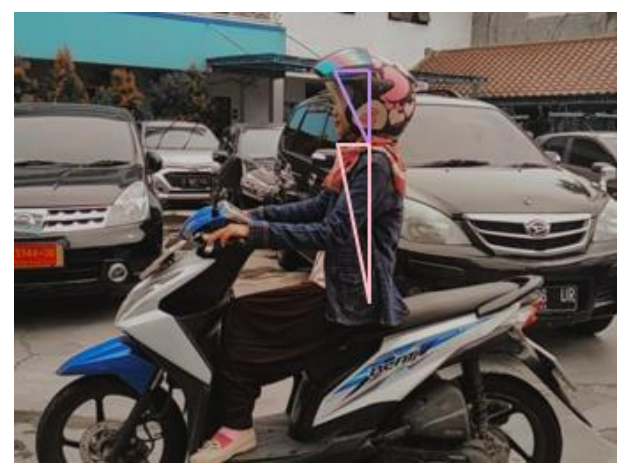

Gambar 1. Postur Pengendara Posisi Samping

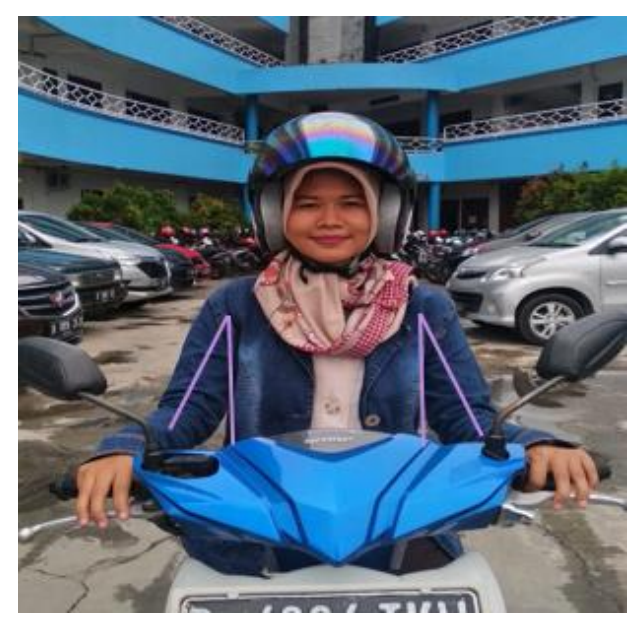

Gambar 2. Postur Pengendara Posisi Depan 


\section{Pengolahan Data}

Pengolahan data yang dilakukan meliputi penilaian postur kerja pada pengendara sepeda motor dengan metode REBA yaitu:

Penilaian Postur Pengendara Pada Saat Duduk jarak $34 \mathrm{~cm}$.

\section{A. Postur Tubuh Grup A}

Postur tubuh bagian leher (neck). Leher membentuk sudut $0-20^{\circ}$ diberi skor $=2$. Postur tubuh bagian batang tubuh (trunk). Batang tubuh membentuk sudut $0-20^{\circ}$ diberi skor $=$ 2. Postur tubuh bagian kaki (legs), kaki dalam posisi normal/seimbang di beri skor = 1 ditambah kaki membentuk sudut $30-60^{\circ}$ diberi skor $=2$. Skor postur kerja Grup A berdasarkan Tabel 1 adalah $=4$. Skor beban $<5 \mathrm{Kg}$ diberi skor $=0$. Total skor untuk Grup A adalah $4+0=4$

\section{B. Postur Tubuh Grup B}

Postur tubuh bagian lengan atas (upper arm), lengan atas membentuk sudut $20-45^{\circ}$ diberi skor $=2$. Postur tubuh bagian lengan bawah (lower arm), lengan bawah membentuk sudut $0-60^{\circ}$ diberi skor $=2$. Postur tubuh bagian pergelangan tangan (wrist). Sudut pergelangan tangan $15^{\circ}$ diberi skor $=2$. Skor postur kerja Grup B berdasarkan Tabel $1=3$. Putaran pergelangan tangan (coupling) adalah good. Skor coupling dari setiap masing- masing bagian tangan. tambah 0 (nol) yang berarti good. Total skor untuk Grup B adalah $3+0=3$.

C. Postur Tubuh Grup C

Untuk memperoleh skor akhir (grand score), skor yang diperoleh untuk postur tubuh grup $A$ dan grup $B$ dikombinasikan ke Tabel C. Kemudian skor REBA adalah penjumlahan dari skor $\mathrm{C}$ dan skor aktivitas.

Skor C ditambah 1 (satu) dengan skor aktifitas apabila satu atau beberapa bagian tubuh bergerak secara statis untuk waktu yang lebih dari satu menit, terdapat beberapa pengulangan pergerakan 4 (empat) kali dalam satu menit (belum termasuk berjalan), dan pergerakan atau perubahan postur lebih cepat dengan dasar yang tidak stabil. Tahap terakhir dari REBA menilai action level dari hasil final skor REBA.

Skor akhir untuk postur duduk dengan $34 \mathrm{~cm}$ berdasarkan Tabel 1 untuk skor $A=4$ dan skor $B$ nya $=3$, maka pada skor $C=4$. Kemudian ditambahakan dengan skor aktivitas = 1 sehingga skor REBA $=4+1=5$, Berdasarkan Tabel 2 skor ( 5 ) tersebut, maka level resiko dari aktivitas pengendara sepeda motor dengan postur duduk berada pada kategori level sedang dan diperlukan tindakan pemeriksaan dan perubahan 
postur kerja beberapa waktu ke depan.

Penilaian Postur Pengendara Pada Saat Duduk jarak $34 \mathrm{~cm}$.

\section{A. Postur Tubuh Grup A}

Postur tubuh bagian leher (neck). Leher membentuk sudut $0-20^{\circ}$ diberi skor $=2$. Postur tubuh bagian batang tubuh (trunk). Batang tubuh membentuk sudut $20-60^{\circ}$ diberi skor $=$ 3. Postur tubuh bagian kaki (legs), kaki dalam posisi normal/seimbang di beri skor = 1 ditambah kaki membentuk sudut $30-60^{\circ}$ diberi skor $=2$. Skor postur kerja Grup A berdasarkan Tabel 1 adalah $=4$. Skor beban $<5 \mathrm{Kg}$ diberi skor $=0$. Total skor untuk Grup A adalah $5+0=5$.

B. Postur Tubuh Grup B

Postur tubuh bagian lengan atas (upper arm), lengan atas membentuk sudut $45-90^{\circ}$ diberi skor $=3$. Postur tubuh bagian lengan bawah (lower arm), lengan bawah membentuk sudut $0-60^{\circ}$ diberi skor $=2$. Postur tubuh bagian pergelangan tangan (wrist). Sudut pergelangan tangan $>15^{\circ}$ diberi skor $=2$. Skor postur kerja Grup B berdasarkan Tabel $1=5$. Putaran pergelangan tangan (coupling) adalah fair dan diberi skor $=1$. Total skor untuk Grup B adalah $5+1=6$.
C. Postur Tubuh Grup C

Skor akhir untuk postur duduk dengan $34 \mathrm{~cm}$ berdasarkan Tabel 1 untuk skor $A=5$ dan skor $B$ nya $=6$, maka pada skor $\mathrm{C}=7$. Kemudian ditambahakan dengan skor aktivitas = 1 sehingga skor REBA $=7+1=8$, Berdasarkan Tabel 2 skor ( 8 ) tersebut, maka level resiko dari aktivitas pengendara sepeda motor dengan postur duduk berada pada kategori level tinggi sehingga perlu segera dilakukan pemeriksaan dan perubahan postur.

\section{SIMPULAN}

Penilaian postur kerja yang tidak alamiah dengan menggunakan metode REBA pada pengendara sepeda motor dengan skor akhir 8 (kategori level tinggi) sehingga perlu segera dilakukan pemeriksaan dan perubahan postur sekarang juga yaitu ketika aktivitas pengendara duduk terlalu mundur sekitar $44 \mathrm{~cm}$ dari ujung sadel sangat berbahaya. Jadi, pengendara motor harus menempatkan posisi duduk di depan sekitar jarak $34 \mathrm{~cm}$ dari ujung sadel, termasuk level sedang yang lebih nyaman secara ergonomik.

\section{PENUTUP}

Terimakasih untuk Ibu Dessy Laksyana Utami, SKM. M.Kes selaku Dosen mata 
kuliah ergonomic yang telah memberikan ilmunya

Terimakasih untuk kepada keluarga yang selalu mensupport penulis hingga akhirnya penulis dapat menyelesaikan jurnal

Terimakasih untuk teman-teman yang selalu mendukung penulis

\section{DAFTAR PUSTAKA}

1. Aviniaa. 2017. Tools Penilaian Risiko Ergonomi - Rapid Entire Body Assessment (REBA) Part 1. [Internet]. Tersedia di https://everydayissafetyday.wordpre ss.com/2017/08/07/tools-penilaianrisiko-ergonomi-rapid-entire-bodyassessment-reba-part-1/

2. Aviniaa. 2017. Tools Penilaian Risiko Ergonomi - Rapid Entire Body Assessment (REBA) Part 2. [Internet]. Tersedia di

https://everydayissafetyday.wordpre ss.com/2017/09/07/tools-penilaianrisiko-ergonomi-rapid-entire-body-

assessment-reba-part-2/

3. Hignett, S. and Mc Atamney, L. 2000. Rapid Entire Body Assesment (REBA). Applied Ergonomics. 2000; 31 (2): 201-205. 